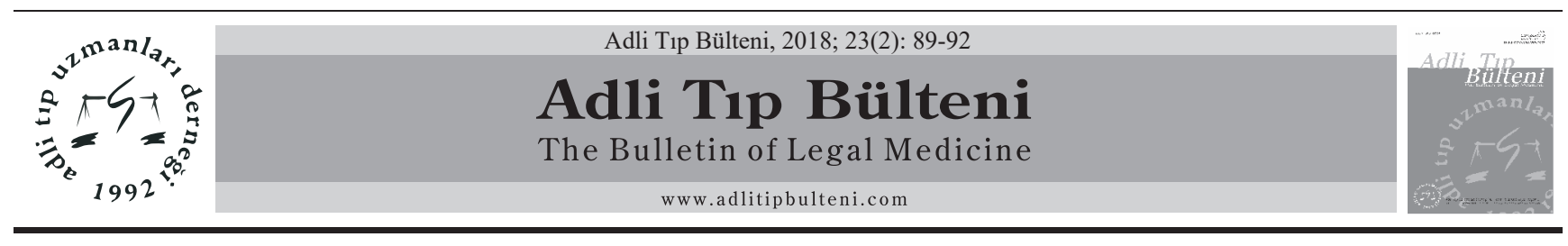

ARAŞTIRMA / RESEARCH ARTICLE

doi: $10.17986 / \mathrm{blm} .2017332861$

\title{
Difficult Decision on Tyroid Surgery of Expert Witness: Complication or Malpractice
}

\section{Tiroid Cerrahisinde Bilirkişinin Zor Seçimi: Komplikasyon veya Malpraktis}

\author{
Ali Rıza Tümerl, Mahmut Şerif Yıldırım ${ }^{1}$ Savaş Koçak² \\ ${ }^{1}$ Hacettepe University Faculty of Medicine Department of Forensic Medicine, Ankara \\ ${ }^{2}$ Ankara University Faculty of Medicine, Department of General Surgery, Ankara
}

\begin{abstract}
Objective: Recurrent laryngeal nerve (RLN) paralysis and hypocalcemia following thyroid surgery have been designated as complication or malpractice. In this study, it was aimed to evaluate surgeons' opinions towards RLN injury and hypocalcemia after bilateral subtotal thyroidectomy (BST) and total thyroidectomy (TT) in nodular goiter and thyroid carcinoma.

Materials and Methods: We prepared a questionnaire to determine approaches of surgeons in such cases. We grouped the respondents according their thyroid surgery experiments and asked them to determine whether it is malpractice or complication in cases with unilateral or bilateral RLN paralysis and hypocalcemia after "bilateral subtotal thyroidectomy" and in cases with unilateral or bilateral RLN paralysis after "total thyroidectomy".

Results: In all groups describing bilateral RLN injury was more common. Problems which are defined as "complication" in cancer patients, were more likely defined as "malpractice" in benign cases. However, these differences were generally not statistically significant.

Conclusion: There is no consensus about malpractice and complication discrimination among physicians. Every physician should evaluate every specific case in its own nature and conditions when asked to determine whether the case should be determined as complication or malpractice.
\end{abstract}

Keywords: Thyroidectomy; Malpractice; Forensic Medicine.

\section{Özet}

Amaç: Tiroid cerrahisinde rekürren laringeal sinir (RLN) hasar1 ve hipokalseminin komplikasyon veya malpraktis olup olmadığ tartışılmaktadır. Bu çalışmada, nodüler guatr ve tiroid kanserlerinde bilateral subtotal tiroidektomi (BST) ve total tiroidektomi (TT) sonrasında hekimlerin RLN hasarına ve hipokalsemiye yönelik görüşlerini değerlendirmek amaçlanmıştır.

Gereç ve Yöntem: Bu olgularda cerrahların yaklaşımlarını belirlemek için bir anket hazırlanmıştır. BST ve TT sonrası tek taraflı ya da bilateral RLN felci ve hipokalseminin, malpraktis ya da komplikasyon olup olmadığı deneyimlerine göre kategorize edilen cerrah katılımcılara sorulmuştur.

Bulgular: Tüm gruplarda bilateral sinir hasarının "malpraktis" olarak tanımlanma oranı daha yüksektir. Ayrıca kanser olgularında "komplikasyon" olarak tanımlanan sorunlar, kanser dışı ameliyatlarda "malpraktis olarak yorumlanabilmiştir. Ancak bu değerlendirme farkları çoğu zaman istatistik anlamlılık taşımamaktadır.

Sonuç: Hekimler arasında tiroid cerrahisi sonrasında malpraktis ve komplikasyon ayırımına ilişkin bir fikir birliği yoktur. Hekimler her olguyu kendi doğasında ve koşullarında değerlendirerek komplikasyon veya malpraktis olarak tanımlamalıdır.

Anahtar Kelimeler: Tiroidektomi; Malpraktis; Adli Tıp.

\section{Introduction}

From beginning of 20th century, thyroid surgeries have been gradually increased (1), and some operational results such as recurrent laryngeal nerve (RLN) injury have been discussed whether it is complication or malpractice. Permanent RLN injury rates was reported as $<2$ $\%$ in various series, and however, its incidence has been

\section{Corresponding Author: Mahmut Şerif Yildırım, MD}

Hacettepe University Faculty of Medicine, Department of Forensic Medicine, Ankara

E-mail:dr.msyildirim@gmail.com

Received:29.08.2017 Revised:16.10.2017 Accepted:27.10.2017 decreased; physicians have been sued for malpractice claims because of mortality and morbidity of thyroid surgery's undesirable results (2). Thus, surgeons -performing especially thyroid operations- are more interested in adverse results such as laryngeal nerve injury and hypocalcemia (3).

A study investigating continued prevalence of malpractice claims against surgeons for RLN injury in 19851991, conducted by Kern showed that RLN injury was a leading disorder $(60 \%)$ related to malpractice lawsuits of surgical endocrine diseases (4). Other adverse results of thyroid surgery are not so rare such as hypocalcemia (6.9-46 \%) (5); however, physicians have not been sued 
for them as well as RLN injury.

Physicians and health care workers have endeavored to minimize such lawsuits (4). Medical expertise has recently been more important due to increasing malpractice claims. The experts have tried to find out if there is complication or malpractice, when they have officially asked for a case. The point is that there is no standardization to describe what is complication or malpractice in a -thyroid- surgery. That's why, expert witnesses have used their own experiences, acquisitions and observations while interpreting the case; however, some guidelines or reviews have also used (6).

In this study, it was aimed to evaluate physicians' opinions towards RLN injury and hypocalcemia after bilateral subtotal thyroidectomy (BST) and total thyroidectomy (TT) in nodular goiter and thyroid carcinoma.

\section{Materials and Methods}

In our country, every specialist who worked for three years in his/her special area, can be expert witness in courts. Judicial authorities can work with any specialist as an expert witness who worked for three years as a specialist of neuroendocrine surgery in cases of RLN paralysis after thyroid surgery procedures to establish whether it is complication or malpractice. We prepared a questionnaire to determine approaches of surgeons in such cases (Supplement).

This questionnaire was set up on two main situations: it asked the respondents to determine whether it is malpractice or complication in cases with unilateral or bilateral RLN paralysis and hypocalcemia after "bilateral subtotal thyroidectomy" and in cases with unilateral or bilateral RLN paralysis after "total thyroidectomy". Also, it is asked from participants to determine legal situation in two common causes of RLN paralysis after thyroid surgery in two common causes of surgery: multinodular goiter and thyroid malignancies. The questionnaire was used firstly in this study, and preliminary evaluation was done on physicians of a University Hospital Surgery Department before it was used in the study. The questionnaire was applied face-to-face to postgraduate residents of surgery departments with general surgeons and neuroendocrine surgery specialists as in two separated groups. First group has two subgroups: residents and general surgeons. General surgeons were divided into categories by their working experience in years as shown in Table 1. Surgeons who have working experience more than five years were considered as expert witness because they are natural expert witnesses in Turkish Criminal Proceedings Code. An informing note has been given about questionnaire and their consent asked verbally before their answers. Questionnaire was performed in an education program which held in 6 Turkish Endocrine Surgery Congress, 2013. Statistical analysis performed with IBM SPSS 20.0.0.1; Massachusetts, USA. Chi-square test performed when sample distribution is suitable and Mann-Whitney $U$ test performed when sample distribution is not suitable for parametric correlation tests.

\section{Results}

Seventy-eight residents and 76 general surgeons participated in this study as group 1 and 80 neuroendocrine surgery specialists as group 2. Most of the general surgeons $(53.9 \%, n=41)$ were working in area for less than five years. Other participants' working experience related to this specific area and type of the hospital which they were occupying shown in (Table 1).

Table 1. The working experience of participants in years.

\begin{tabular}{|l|c|c|c|c|}
\hline & \multicolumn{4}{|c|}{ Group 1 } \\
\hline & \multicolumn{2}{|c|}{ Specialist } & \multicolumn{2}{c|}{ Resident } \\
\hline Working Experience & N & \% & n & \% \\
\hline $\mathbf{0 - 5}$ & 41 & 53.9 & 78 & 100 \\
\hline $\mathbf{6 - 1 0}$ & 19 & 25 & & \\
\hline $\mathbf{1 1 - 1 5}$ & 5 & 6.6 & & \\
\hline $\mathbf{1 6 - 2 0}$ & 8 & 10.5 & & \\
\hline $\mathbf{2 1 - 2 5}$ & 2 & 2.6 & & \\
\hline $\mathbf{2 6 +}$ & 1 & 1.3 & & \\
\hline \multicolumn{1}{|c|}{ Total } & 76 & 100 & 78 & 100 \\
\hline & & & & \\
\hline Type of the Hospital & & & & \\
\hline University Hospital & 17 & 22.4 & 37 & 47.4 \\
\hline Edu. \& Res. Hospital & 31 & 40.8 & 41 & 52.6 \\
\hline State Hospital & 26 & 34.2 & & \\
\hline Private Hospital & 2 & 2.6 & & \\
\hline \multicolumn{1}{|c|}{ Total } & 76 & 100 & 78 & 100 \\
\hline & & & & \\
\hline
\end{tabular}

Edu. \& Res.: Education and Research Hospital

There were 80 participants in group 2 and 47 (58.8\%) of them were performing a thyroid operation less than 50 times in a year. The participants' working places are shown in (Table 2). 
Table 2. The participants' working places and type of the hospital which they were occupying.

\begin{tabular}{|c|c|c|}
\hline & \multirow{2}{*}{\multicolumn{2}{|c|}{$\begin{array}{c}\text { Group } 2 \\
\text { Specialist }\end{array}$}} \\
\hline & & \\
\hline $\begin{array}{c}\text { Number of Thyroid Operation } \\
\text { in a Year }\end{array}$ & $\mathbf{n}$ & $\%$ \\
\hline $0-50$ & 47 & 58.8 \\
\hline $50<$ & 33 & 41.2 \\
\hline Total & 80 & 100 \\
\hline \multicolumn{3}{|l|}{ Type of the Hospital } \\
\hline University Hospital & 9 & 11.2 \\
\hline Edu. \& Res. Hospital & 18 & 22.5 \\
\hline State Hospital & 30 & 37.5 \\
\hline Private Hospital & 23 & 28.8 \\
\hline Total & 80 & 100 \\
\hline
\end{tabular}

Edu. \& Res.: Education and Research Hospital

\section{First Group}

Overwhelming of residents $(93.6 \%)$ thought that injury of unilateral RLN after TT in nodular goiter is a complication. Answers of first group are shown in Table 3. Therefore, there was statistically significant difference in the replies for injury of RLN in nodular goiter between BST and TT for residents ( $\mathrm{p}=0.017)$.

Significant difference was found for injury of bilateral RLN between BST and TT cases, for both specialists and residents $(\mathrm{p}<0.001)$.

Statistically significant difference was found for permanent hypocalcemia between BST and TT cases, for both specialists $(p=0.023)$ and residents $(p=0.005)$.
There was no statistically significant difference for injury of unilateral RLN after TT between nodular goiter and thyroid carcinoma for both groups ( $\mathrm{p}>0.05)$.

Statistically significant difference was found for injury of bilateral RLN after TT between nodular goiter and thyroid carcinoma for specialists $(\mathrm{p}<0.001)$ and residents $(p=0.002)$.

Statistically significant difference was found for permanent hypocalcemia after TT between nodular goiter and thyroid carcinoma for specialists $(p=0.001)$ and residents $(p=0.001)$.

\section{Second Group}

Significant difference was found for injury of RLN in nodular goiter between BST and TT in second group $(\mathrm{p}=0.002)$.

There was significant difference in injury of bilateral RLN between BST and TT $(\mathrm{p}<0.001)$.

Significant difference was found for permanent hypocalcemia between BST and TT $(\mathrm{p}<0.001)$.

There was significant difference for injury of unilateral RLN after TT between nodular goiter and thyroid carcinoma $(\mathrm{p}<0.001)$.

There was significant difference for injury of bilateral RLN after TT between nodular goiter and thyroid carcinoma $(\mathrm{p}<0.001)$.

Significant difference was found for permanent hypocalcemia after TT between nodular goiter and thyroid carcinoma $(\mathrm{p}<0.001)$.

There was no significant difference for numbers of thyroid operation in a year $(p>0.005)$. Answers of second group are shown in Table 3.

Table 3. Answers of participants.

\begin{tabular}{|c|c|c|c|c|c|c|c|c|c|c|c|c|c|}
\hline & & \multicolumn{4}{|c|}{ Injury of Unilateral RLN } & \multicolumn{4}{|c|}{ Injury of Bilateral RLN } & \multicolumn{4}{|c|}{$\begin{array}{c}\text { Permanent } \\
\text { Hypocalcemia }\end{array}$} \\
\hline & \multicolumn{2}{|c|}{$\mathrm{C}$} & \multicolumn{2}{|c|}{ M } & \multicolumn{2}{|c|}{$\mathrm{C}$} & \multicolumn{2}{|c|}{ M } & \multicolumn{2}{|c|}{$\mathrm{C}$} & \multicolumn{2}{|c|}{ M } & \\
\hline & n & $\%$ & $\mathbf{n}$ & $\%$ & n & $\%$ & $\mathrm{n}$ & $\%$ & $\mathrm{n}$ & $\%$ & $\mathbf{N}$ & $\%$ & \\
\hline \multirow{3}{*}{$\begin{array}{l}\text { After BST in Nodular } \\
\text { Goiter; }\end{array}$} & S1 & 54 & 71.1 & 22 & 28.9 & 32 & 42.1 & 44 & 57.9 & 45 & 59.2 & 31 & 40.8 \\
\hline & R1 & 57 & 73.1 & 21 & 26.9 & 24 & 30.8 & 54 & 69.2 & 37 & 47.4 & 41 & 52.6 \\
\hline & S2 & 55 & 68.8 & 25 & 31.2 & 27 & 33.8 & 53 & 66.2 & 44 & 55 & 36 & 45 \\
\hline \multirow{3}{*}{$\begin{array}{l}\text { After TT in Nodular } \\
\text { Goiter; }\end{array}$} & S1 & 65 & 85.5 & 11 & 14.5 & 50 & 65.8 & 26 & 34.2 & 62 & 81.6 & 14 & 18.4 \\
\hline & R1 & 73 & 93.6 & 5 & 6.4 & 40 & 51.3 & 38 & 48.7 & 52 & 66.7 & 26 & 33.3 \\
\hline & $\mathbf{S 2}$ & 75 & 93.8 & 5 & 6.2 & 49 & 61.2 & 31 & 38.8 & 58 & 72.5 & 22 & 27.5 \\
\hline \multirow{3}{*}{$\begin{array}{l}\text { After TT in Thyroid } \\
\text { Carcinoma; }\end{array}$} & S1 & 72 & 94.7 & 4 & 5.3 & 59 & 77.6 & 17 & 22.4 & 70 & 92.1 & 6 & 7.9 \\
\hline & R1 & 78 & 100 & - & - & 60 & 76.9 & 18 & 23.1 & 69 & 88.5 & 9 & 11.5 \\
\hline & S2 & 77 & 96.2 & 3 & 3.8 & 66 & 82.5 & 14 & 17.5 & 70 & 87.5 & 10 & 12.5 \\
\hline
\end{tabular}

BST: Bilateral Subtotal Thyroidectomy, TT: Total Thyroidectomy, RLN: Recurrent Laryngeal Nerve, S1: Specialists in first group ( $\mathrm{n}=76$ ), R1: Residents in first group $(n=78)$, S2: Specialists in second group $(n=80)$, C: Complication, M: Malpractice 


\section{Cross}

There was no significant difference among specialists and residents, and among specialists in first group and residents for all questions ( $\mathrm{p}>0.005$ ).

There was no statistically significant difference between specialists in both groups, and specialists in second group and residents for all questions $(\mathrm{p}>0.005)$. (Table 3)

\section{Discussion}

Many general surgeons encounter questions about malpractice assertions for judicial processes in their professional and/or academic life. However only a few of them have education for expert witness process and most of them have no objective education about it.

RLN paralysis is one of the unwanted outcomes of thyroid surgery. In malpractice cases, the physician who have been asked for expert witness by judicial authorities must have enough knowledge about current approaches and procedures about the case (7) as well as information about judicial process and objectives of an expert witness. Although objectivity is the most important thing for an expert witness but most of physicians do not know how to be objective. Most physicians confirm their opinion with literature, but sometimes there may be no clue in literature about the specific case and physician makes his/her own decision for the case $(8,9)$ and this makes objectivity more difficult.

Many determinants affect objectivity in expert witness process: professional career, personal skills, own approach of the physician to the case and etc. (10). However, there is no clue in literature whether the surgical methods, cause of surgery and severity of unwanted outcomes affect physicians' decision or not. In our study, there was no significant difference between residents, general surgeons and neuroendocrine surgeons. It is possible to state that any general surgery specialist's approach is not different from neuroendocrine surgeons. We found that establishing objective decision is difficult in medical litigations. There was no consensus in any situations in our study. Also, it can be stated as an outcome of our study that cause of surgery and nature of surgical procedure are also be determinants of physicians while they are making decision between complication and malpractice.

According to the existing legislation in Turkey, all health workers who have worked in the field for three years are defined as witness experts in their fields. Therefore, surgeons who completed five years in the first group and the entire second group consisted of experts. However, the most important limitation of this study is the inability of the study groups to compare between surgeons who have previously been witness experts and who have not.

\section{Conclusion}

It is hard to say there is a consensus about malpractice and complication discrimination among physicians. This makes reaching an objective decision difficult from expert witness and it brings also necessity to objectify complication and malpractice discrimination with several discussions and international meetings. Also, every physician should evaluate every specific case in its own nature and conditions when it asked to determine whether the case should be determined as complication or malpractice.

Conflict of Interest: The authors have no potential conflicts of interest to be disclosed.

Financial disclosures: No financial support provided for this work.

\section{References}

1. Abadin SS, Kaplan EL, Angelos P. Malpractice litigation after thyroid surgery: the role of recurrent laryngeal nerve injuries, 1989-2009. Surgery. 2010;148(4):718-23. DOI: 10.1016/j.surg.2010.07.019

2. Schulte KM, Röher H. [Medico-legal aspects of thyroid surgery]. Der Chirurg; Zeitschrift fur alle Gebiete der operativen Medizen. 1999;70(10):1131-8. DOI: 10.1007/ s001040050

3. Wagner H, Seiler C. Recurrent laryngeal nerve palsy after thyroid gland surgery. British Journal of Surgery. 1994;81(2):226-8. DOI: 10.1002/bjs. 1800810222

4. Kern KA, Hartford C. Medicolegal analysis of errors in and treatment of surgical endocrine. Surgery. 1993; 114(6):1167-1174

5. Curić Radivojević R, Prgomet D, Markešić J, Ezgeta C. Hypocalcaemia after Thyroid Surgery for Differentiated Thyroid Carcinoma: Preliminary Study Report. Collegium Antropologicum. 2013;36(2):73-8.

6. Hayward RA, Hofer TP. Estimating hospital deaths due to medical errors: preventability is in the eye of the reviewer. Jama. 2001;286(4):415-20. DOI: 10.1001/jama.286.4.415

7. American Collage of Surgeons. Statement on the physician acting as an expert witness. Journal of the American College of Surgeons. 2004;199(5):746-7. DOI: 10.1016/j.jamcollsurg.2004.07.015

8. Kunin CM. The expert witness in medical malpractice litigation. Ann Intern Med. 1984;100(1):139-143. DOI: 10.7326/0003-4819-100-1-139

9. Bal BS. The expert witness in medical malpractice litigation. Clinical orthopaedics and related research. 2009;467(2):383-91. DOI: 10.1007/s11999-008-0634-4

10. Commons ML, Gutheil TG, Hilliard JT. On humanizing the expert witness: A proposed narrative approach to expert witness qualification. Journal of the American Academy of Psychiatry and the Law Online. 2010;38(3):302-4. 